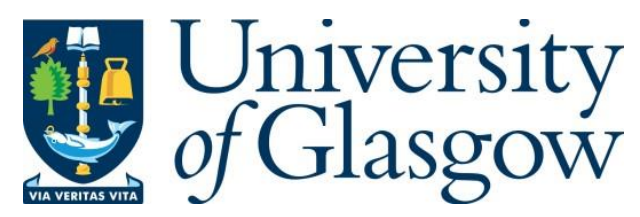

Erickson, K., Kretschmer, M. and Mendis, D. (2019) An empirical approach to the public domain. In: Drexl, J. and Kamperman Sanders, A. (eds.) The Innovation Society and Intellectual Property. Series: European intellectual property institutes network series. Edward Elgar Publishing: Cheltenham, UK ; Northampton, MA, USA, pp. $87-$ 116. ISBN 9781789902341.

There may be differences between this version and the published version. You are advised to consult the publisher's version if you wish to cite from it.

http://eprints.gla.ac.uk/207469/

Deposited on: 9 January 2020

Enlighten - Research publications by members of the University of Glasgow http://eprints.gla.ac.uk 
Authors' note: This is the pre-print author-submitted version.

Please reference as:

Erickson, K., Kretschmer M. and Mendis D. (2019) 'An empirical approach to the public domain'; Chapter 4 (pp. 87-117) in J. Drexl and A. Kamperman Sanders (eds.) The Innovation Society and Intellectual Property; Cheltenham, UK: Edward Elgar.

\section{An empirical approach to the public domain}

\section{Kris Erickson, Martin Kretschmer and Dinusha Mendis}

\section{$1 \quad$ INTRODUCTION}

Creative practices in the digital era and access to the reservoir of works and ideas that we call 'the public domain' are intertwined in complex and complementary ways. ${ }^{1}$ Digitalisation has made it possible for the first time for users to access a near infinitude of works - including copyright works - as well as to create and distribute digital copies of works across borders and through a range of technical devices. The features of digital technology that make this possible include standardisation (for example, the possibility for images encoded in a standard format to be displayed on many devices) and convergence (the ability of a single digital device to perform many tasks). From a digital point of view, a book, a painting and a video game are broadly equivalent - they can be reproduced as files containing binary information about how to display them to a user.

A number of legal scholars and economists have discussed the public nature of digital information goods. ${ }^{2}$ A major feature of new media markets is that one user's consumption of a digital copy does not impede another's use or

\footnotetext{
${ }^{1}$ P. Samuelson, 'Mapping the Digital Public Domain: Threats and Opportunities' (2003) 66 L. \& Contemp. Probls. 147; R. Pollock, 'The Value of the Public Domain' (London: Institute for Public Policy Research, 2006), availa- ble at http://rufuspollock.org/papers/value_of_public_domain.ippr.pdf (accessed 30 September 2018); L. Dobusch, 'The Digital Public Domain: Relevance and Regulation' (2012) 21(2) Info. \& Comms. Tech. L. 179.

${ }^{2}$ Y. Benkler, 'Free as the Air to Common Use: First Amendment Constraints on Enclosure of the Public Domain' (1999) 74 N.Y.U. L. Rev. 354; M. Rose, Authors and Owners: The Invention of Copyright (Cambridge, MA and London, UK: Harvard University Press, 1993); J. Boyle, Public Domain: Enclosing the Commons of the Mind (New Haven, CT and London, UK: Yale University Press, 2010).
} 
enjoyment of the same work. Because of the global, interconnected nature of the Internet, information goods are also nonexcludable: it has proven difficult to limit access to informatioonnce a single initial copy has been made available in a digital format, a feature of concern to traditional media industries and rightholders.

Works legally in the public domain are public in the manner of digital information goods discussed above; however, they possess further public goods qualities related to creative transformation. Works and ideas in the public domain may be taken up and used by others in the creation of new expressions, without the need to obtain permission or pay a licence fee. The status of the public domain is therefore significant to both consumers and producers. Consumers may enjoy works in the public domain lawfully without infringing copyright. Producers may freely take inspiration from an underlying public domain expression or idea without creative or financial restrictions. The original creator (or successor in title) of a copyright work cannot refuse permission to a creator who wishes to adapt or transform the work, potentially leading to innovation and new creativity.

Broadly, there are two underlying conceptualisations of the public domain implicit in the literature; both are valid, depending on the perspective of the user and on one's particular view of the relationship between law and practice.

On one hand, certain legal scholars have described the public domain as a negative space defined by the absence of formal intellectual property rights. ${ }^{3}$ In this conceptualisation, the public domain exists where copyright does noteither because the subject matter is beyond the scope of copyright, or because the time limited monopoly granted by copyright has lapsed. Enumerating the size and value of such a public domain involves largescale cataloguing of works outside of copyright protection and measuring their availability and use. $^{4}$

On the other hand, a different view of the public domain adopts what may be called a 'behavioural' approach, focusing instead on all activities possible by users without seeking permission. This includes the range of uses enabled, or tolerated, on an individualised and context specific basis. ${ }^{5}$ This approach expands consideration about what materials can be in the public domain, but

\footnotetext{
${ }^{3}$ W. Landes and R.A. Posner, 'Indefinitely Renewable Copyright' (2003) 70 U. Chi. L. Rev. 471, 475.

${ }^{4}$ R. Pollock and P. Stepan, 'The Size of the EU Public Domain' (2010) available at www.repository.cam.ac.uk/bitstream/handle/1810/242071/cwpe1046.pdf (accessed 30 September 2018); P. Heald, 'Property Rights and the Efficient Exploitation of Copyrighted Works: An Empirical Analysis of Public Domain and Copyrighted Fiction Bestsellers' (2007) 92 Minn. L. Rev. 1031.

${ }^{5}$ Benkler, n. 2 above; Dobusch, n. 1 above.
} 
renders more complex the meaning of 'public', since certain types of use are privileged according to one's location and intent. The size and shape of the public domain shifts depending on the territory of the creator as well as the territories in which one seeks to exploit a derivative work, with important implications for users how to determine possible permitted uses. For example, if the scope of exceptions differs, the same act will be considered an infringement in one country and not in another. If practices differ, rightholders may tolerate certain acts in one country and not another. Dobusch cautions that '[a]n empirical assessment of the relevance of the public domain must therefore also take into account actual practices of contribution to as well as usage and appropriation of these different public domain phenomena' ${ }^{6}$

This chapter, based on a larger project exploring copyright and the value of the public domain (hereinafter, the Study) ${ }^{7}$ seeks to address the call by Dobusch to empirically address the value of the public domain in relation to actual use. Drawing on the Study, this chapter outlines and explains the methodological approach adopted in defining the 'public domain'. Having explored the various underlying conceptualisations of the public domain in the literature, the Study adopted a definition (specific to the UK context) covering four main types of materials, as set out below:

(1) Copyright works that are out of term of protection: namely, literary and artistic works created by authors who died prior to 1944;

(2) Materials that were never protected by copyright: namely, works from antiquity and folklore;

(3) Underlying ideas not being substantial expression: namely, inspiration taken from preexisting works, including genre, plot or ideas;

(4) Works offered to the public domain by their creator: namely, certain free and open-licensed works without restrictions.

It will be argued that this definition encapsulates the practicability of use of the public domain by all potential users (both commercial and noncommercial) without requiring permission from a rightholder, while presupposing a sufficiently precise definition that would permit measurement of its value. Furthermore, it permitted the researchers to critically appraise theories of

\footnotetext{
${ }^{6}$ Dobusch, n. 1 above, 6.

${ }^{7}$ Report commissioned by the UK Intellectual Property Office (UKIPO) and supported by the Economic and Social Research Council (ESRC Reference: ES/ K008137/1) titled 'Copyright and the Value of the Public Domain: An Empirical Assessment', carried out by the present authors with a team including P. Heald and F. Homberg. The overall project was led by K. Erickson and M. Kretschmer (CREATe, University of Glasgow), and the legal analysis was led by. D. Mendis. Available at www.gov.uk/government/uploads/system/uploads/attachment_data/file/415014/ Copyright_and_the_value_of_the_public_domain.pdf (accessed 30 September 2018).
} 
creativity and innovation that explain how value might be generated from nonexclusive use of ideas and works available to all.

The nonrival, nonexcludable nature of the public domain would seem to limit its appeal to creators in a competitive market, while any observed commercial uptake of public domain material consequently raises important questions. For example, what stimulates creators to invest in transforming or republishing public domain works? How do firms gain and sustain competitive advantage when exploiting freely available public domain materials? What policy options are available to promote market uptake of public domain materials, and what are the likely impacts?

The chapter will proceed by providing an overview of current ambiguity in the boundaries of the public domain in recent UK and selected international case law, as well as resulting challenges raised for potential users. Thereafter, the chapter will develop and justify the working definition of the public domain adopted for the purposes of the empirical Study, which includes works, portions of works and materials which are available for uptake by all, regardless of the context of intended use.

\section{DEFINING THE PUBLIC DOMAIN}

There has been much debate and much written about the definition of the public domain and its relationship with copyright law. These debates have mainly focused on defining the concept and the contours of the public domain against an advancing copyright regulatory framework on the one hand, ${ }^{8}$ while taking into account the technological landscape on the other. Although a brief overview of the meaning and boundaries of the public domain is needed, the aim of this section is not to restate or summarise the arguments, which have already been established by leading commentators in this field. ${ }^{9}$ Rather the aim is to explore the 'boundary' between copyright law and the public domain, and identify from concrete examples where the uncertainties lie. Some uses of public domain work are straightforward, such as republication of old, out of copyright literary works. However, much current digital creativity involves remixing and recombination of work that may incorporate ideas or elements

\footnotetext{
${ }^{8}$ C. Waelde and H. MacQueen, The Many Faces of the Public Domain (Cheltenham, UK \& Northampton, MA: Edward Elgar, 2007).

9 See commentaries by C. Waelde, R. Deazley, F. McMillan, G. Davies, F.M. Grosheide, G. Dutfield, J. Gibson, R. Susskind, J. Cahir and Ors in C. Waelde and H. MacQueen, n. 8 above. See also K. Erickson and M. Kretschmer (eds.), 'Research Perspectives on the Public Domain: Digital Conference Proceedings', CREATe Working Paper Series 2014/3, available at https://papers.ssrn.com/sol3/papers.cfm ?abstract_id=2739847 (accessed 30 September 2018).
} 
from others. The scope of protection offered by copyright is therefore significant in determining what ideas or aspects of an expression remain available for uptake in the creation of new works. Furthermore, the position of copyright with respect to historical facts and common elements has raised interesting and complex legal and regulatory questions.

Ronan Deazley defines the contours of the public domain as a series of categories incorporating: ${ }^{10}$ (i) those works which do not qualify for copyright protection; (ii) those works which do but are out of copyright term; (iii) those works where permission to use has been granted by the copyright owner a priori; and (iv) such parts of works which fall on the unprotectable side of the idea-expression line, which are allowed for within the statutory framework (taking of an insubstantial part, the permitted acts), or which are permissible as a result of judicial intervention with the regime at common law (on public policy grounds, or as being in the public interest). ${ }^{11}$ These interrelated definitions are expanded further, with reference to legal decisions concerning actual use where the legal boundary of copyright protection was uncertain.

\section{COPYRIGHT WORKS OUTSIDE OF TERM}

In the UK, in conformity with secondary EU law, ${ }^{12}$ copyright in literary, dramatic, musical and artistic works lasts for 70 years from the death of the author, with the work entering the public domain on 1 January of the calendar year following the anniversary of their passing. When a work has more than one author, the term is calculated from the date of death of the last surviving author. For works of anonymous authorship, the copyright term lasts for 70 years from the date of first publication. UK copyright in previously unpublished work does not presently expire until 1 January $2039 .{ }^{13}$

\footnotetext{
${ }^{10}$ Deazley, n. 9 above, 27.

${ }^{11}$ Ibid., 30-31.

${ }^{12}$ See Directive 2006/116/EC of the European Parliament and of the Council of 12 December 2006 on the term of protection of copyright and certain related rights (codified version) [2006] OJ L372/12.

${ }^{13}$ The current term expiry of 31 December 2039 was introduced by the UK Copyright Designs and Patents Act 1988 and applies to all works created, but not pub- lished before 1 August 1989, where the author died before 1 January 1969. Policy options are being explored to address older unpublished material at the request of archive institutions and other users. The UK IPO's 'Consultation on reducing the duration of copyright in unpublished ('2039') works in accordance with section 170(2) of the Copyright, Designs and Patents Act 1988' closed on 12 December 2014, available at www.gov.uk/government/uploads/system/uploads/attachment_data/file/368811/ consultation-on-unpublished-works.pdf (accessed 30 September 2018).
} 
Due to the length of the copyright term and the relatively recent technological developments in broadcast and digital media, the bulk of work presently in the public domain consists of literary texts, musical compositions, illustrations and photographs. ${ }^{14}$ The majority of television programmes, sound recordings and films from the twentieth century remain in copyright since they rely on relatively recent technological developments and media. No digital interactive materials or software (protected as a literary work) have yet entered the copyright public domain through term expiration. Software will begin to enter the public domain from around the time of writing, when more than 70 years will have elapsed since the earliest computer software was developed after the Second World War.

\subsection{Uses and Challenges}

Once a work enters the public domain via term expiry, contents of the expression may be used freely by anyone, without the need to seek permission from the original rightholder. The work may be used commercially or noncommercially. Such use may include republication of the complete original work, or derivative use of parts of the work.

Because the entire contents of the original expression are available for uptake once a work enters into the public domain, downstream users of the work may seek to reproduce it or make it available to the public in its entirety. One set of users of public domain works is archival institutions wishing to preserve and share works of historical importance. Common uses of public domain materials by cultural institutions include scanning, digitising, exhibiting and distributing copies of works.

Other users of a work in the public domain may include commercial publishers or broadcasters who wish to make the original work commercially available in its entirety. In the case of publishing, a new typographical copyright will exist in the new edition upon republication. However, other publishers are free to work with the same underlying public domain source material to create their own editions.

A third set of users of out of copyright work includes creators wishing to adapt or transform a substantial part of the original in the creation of a new derivative work. Derivative users may seek to do this with works that are still copyright protected, by obtaining the permission of the rightholder. However, some rightholders may choose not to make their work available for derivative

\footnotetext{
${ }^{14}$ Pollock and Stepan, n. 4 above.
} 
uptake. ${ }^{15}$ Once the copyright term has passed, these works become freely available for use, which may include adaptation from one medium to another, or recombination with other works.

The aforementioned Study identified through an interview research sample, many examples of creative firms using copyright works that were out of term. ${ }^{16}$ For example, one dance and theatre company organised a production of Dracula, drawing inspiration from the original gothic novel by Bram Stoker. A children's book publisher created a series of books reproducing artwork by famous European painters, some still in copyright and others out of copyright. Another entrepreneur raised $£ 75,000$ on Kickstarter to create an interactive 3D world called Ever, Jane where players may act out scenes from novels by Jane Austen. Each of these undertakings was inspired and facilitated by the out of copyright status of the underlying source material. By contrast, we can imagine a product such as an interactive game developed using a copyright licence obtained from a third party rightholder. In such a case, allowing unscripted and unmoderated user generated inputs might not be acceptable from the point of view of the rightholder, due to brand protection and other reputational or moral concerns. Public domain works are not subject to such creative constraints.

While the duration of copyright term is largely straightforward, complications often arise when seeking to determine the status of a work (for example, to seek permission from the rightholder). Works of collaborative authorship present the most difficulty. In the case of cinematographic works, the UK copyright term is calculated from the date of death of the principal director, the author of the screenplay, the author of the dialogue and the composer of any original music for the film, whoever may have lived longest. Consequently, it is often cost prohibitive to determine the public domain status of old films. A result of the high cost of rights clearance for certain types of works, as explored in the literature on orphan works, is that a large amount of material that is actually in the public domain remains unavailable and underused because its status has not been ascertained. ${ }^{17}$

\footnotetext{
${ }^{15}$ As was famously the case with the works of James Joyce, which were not widely licensed for adaptation prior to their entry into the public domain on 1 January 2012.

${ }^{16}$ See UKIPO-ESRC Study, n 7 above, 24-37 ('Study 1: Uptake and Exploitation of Public Domain Works by UK Firms').

17 M.A. Pallante, 'Orphan Works and Mass Digitization: Obstacles and Opportunities' (2012) 27 Berkeley Tech. L.J. 1251; R. Deazley and V. Stobo, 'Archives and Copyright: Risk and Reform', CREATe Working Paper 2013/3, available at www .create.ac.uk/private/uploads/20140912-110938_CREATe-Working-Paper-2013-03 .pdf (accessed 30 August 2018).
} 
Further complications concern the territoriality of copyright term. A work may be in the public domain in the United Kingdom, but remain in copyright in a different jurisdiction. Due to the global nature of the digital media industry, this can result in legal risk to derivative creators and publishers when they seek to make a work based on public domain materials commercially available in different markets.

\section{SUBJECT MATTER THAT DOES NOT QUALIFY FOR COPYRIGHT PROTECTION}

In addition to works for which copyright protection has expired, the public domain also includes subject matter that has never qualified for copyright protection.

According to Deazley, '[i]f the institution of copyright necessitates permission before use, then the public domain allows for use without the need for permission. Clearly this would include subject-matter which, for whatever reason, fail to qualify as copyright protected in the first place' ${ }^{18}$

One category of such public domain works relates to those that pre-date the establishment of the modern copyright framework, and consequently have never enjoyed any copyright protection. These works include myths and stories from antiquity, religious iconography and texts, and a multitude of other literary and artistic expressions that were produced after the invention of writing but before the formalisation of the European copyright system, which began during the eighteenth century.

Furthermore, more recent material can be in the public domain due to being outside of the scope of copyright law, if it does not satisfy the necessary requirements to attract copyright, such as that it is not an expression, or does not meet the threshold of originality required for protection. For example, a single word would not qualify as a literary work, ${ }^{19}$ and therefore it is not protectable by copyright law. Likewise, copyright would not subsist in the unoriginal shape of an object. ${ }^{20}$

\footnotetext{
${ }^{18}$ R. Deazley, Rethinking Copyright - History, Theory, Language (Cheltenham, UK and Northampton, MA: Edward Elgar, 2006) 107.

${ }^{19}$ Exxon Corp $v$ Exxon Insurance (1982) Ch 119. In this case, the claim was in relation to the single word 'Exxon' invented by the plaintiffs. However, the court held that being 'original', 'literary' and a 'work' is not necessarily enough to attract copyright protection when it concerns a single word. See C-5/08 Infopaq [2009] ECR I-6569 = ECLI:EU:C:2009:465, para. 46: 'Words as such do not, therefore, constitute elements covered by the protection.'

${ }^{20}$ Interlego AG v Tyco Industries Inc [1989] AC 217. This case related to the design of Lego bricks. The design of the Lego brick in question differed in technical information as to dimensions; however, the visual impression remained much the same.
} 
This category of public domain material is diverse and includes nonfixed expressions such as oral traditions and folk tales, common sayings and phrases, layperson knowledge, historical events, compendiums of facts, scientific discoveries and other ideas that do not qualify for copyright protection. ${ }^{21}$

\subsection{Uses and Challenges}

Users of public domain materials pre-dating the modern copyright framework include both public and private organisations, and their uses often correspond with the treatment of modern works where the term of protection has lapsed. For public institutions, such uses might include archiving, preservation, communication to the public and education.

The businesses and creators identified in the Study did make use of such myths and stories pre-dating copyright. One product consisted of an illustrated bestiary comprised of Biblical creatures using the eighteenth century engravings by the Comte de Buffon..$^{22}$ In this example, the researchers observed that multiple sources of public domain and third party copyright materials can often be combined in the production of new works. ${ }^{23}$

Potential users of this category of public domain materials may face challenges related to the legal uncertainty and risk associated with use, even if permissible. For example, the originator of an idea not protectable by copyright (such as the populariser of a common expression) may believe that they own a copyright in the idea and may pursue legal action against parties that use the material. The perceived risk of a legal challenge may dissuade creators from making use of ideas and works in the public domain, resulting in underexploitation.

The public domain status of folklore or traditional knowledge in some jurisdictions can be ambiguous. Folklore is based on the traditions, cultures and beliefs of a society and usually transmitted orally from generation to generation, thereby being modified repeatedly through transmission. ${ }^{24}$ Therefore, prima facie, folklore would not satisfy the originality and fixation require-

The court held that while skill and labour had been expended on the changes, they did not produce any significant visual alterations and therefore where not original artistic works and not entitled to copyright protection.

${ }^{21}$ Samuelson, n. 1 above, 151.

22 See www.kickstarter.com/projects/1 161793193/the-book-of-blessed-beasts (accessed 31 August 2017).

${ }^{23}$ The UKIPO-ESRC Study, n. 7 above, 10.

${ }^{24}$ L. Dirar, 'Folklore Protection in the Eritrean Context: Legal Issues and Choices’ (2012) 20(2) African J. Int'l \& Comp. L. 229, 230. 
ments of copyright. However, the link between copyright law and folklore arises from the way folklore is expressed. ${ }^{25}$

Two Australian cases demonstrate this uncertainty. In the first matter, Yumbulul v Reserve Bank of Australia ${ }^{26}$ a commemorative banknote reproduced the design of a Morning Star Pole created by Terry Yumbulul, an Aboriginal artist. The judge stated that 'Australia's copyright law does not provide adequate recognition of Aboriginal community claims to regulate the reproduction and use of works which are essentially communal in origin' ${ }^{27}$

Subsequently, however, in the matter of Milpurrurru $v$ Indofurn Pty Ltd and others ${ }^{28}$ the Australian courts demonstrated a more favourable approach towards the protection of traditional Aboriginal work. ${ }^{29}$ This case concerned woollen carpets sold by the respondents that reproduced artwork of Aboriginal artists, represented by the applicants. The judge, relying on section 115(4) of the Australian Copyright Act 1968 (as amended), which provides for the additional grant of damages in a case of flagrant infringement, awarded $\$ 1,500$ per artwork against each of the respondents. However, more significantly, relying on the UK case Williams $v$ Settle ${ }^{30}$ stating that anger and distress suffered by those around the copyright owner constitute part of that person's injury, ${ }^{31}$ Judge Von Doussa awarded an additional sum of $\$ 700,000$ under section 115(4) to 'reflect the harm suffered in their cultural environment'. ${ }^{32}$

A number of cases in the UK courts have hinged on the question of uptake of 'common elements' available to all, when one creator has previously made use of those elements in an artistic expression. For example, common elements might include the iconic London double decker bus, a well known street or background, or occult themes such as magic or wizardry. These cases have

\footnotetext{
${ }^{25}$ Ibid., 233.

${ }^{26}$ Yumbulul v Reserve Bank of Australia (1991) 21 IPR 481.

${ }^{27}$ Ibid., 490.

${ }^{28}$ Milpurrurru v Indofurn Pty Ltd and others (1994) 130 ALR 659.

${ }^{29}$ M. Blakeney, 'Protecting Expressions of Australian Aboriginal Folklore under Copyright Law' (1995) 17(9) E.I.P.R. 442,445.

30 Williams $v$ Settle [1960] 1 WLR 1072, 1086-7. This case involved the infringement of a photograph of the applicant's father who had been murdered. Damages were awarded on the consideration of the 'total disregard not only of the legal rights of the plaintiff regarding copyright but of his feelings and his sense of family dignity and pride' (Sellers LJ 1082).

31 'There is continuing uncertainty as to the appropriateness of use of traditional images on products which utilise non-traditional mediums, and on carpets designed to be walked upon.' Milpurrurru v Indofurn Pty Ltd and others (1994) 130 ALR 659, Von Doussa J, para. 18.

${ }^{32}$ Milpurrurru v Indofurn Pty Ltd and others [1994] 130 ALR 659 (Von Doussa J, para. 159).
} 
raised questions as to whether such elements can be protected and in what circumstances their arrangements constitute an original expression.

Perhaps the most striking recent case in this context is that of Temple Island Collections Ltd $v$ New English Teas ${ }^{33}$ more commonly known as the 'Red Bus' case. In this case, Temple Island Collections Ltd claimed that the defendants' work (photograph) infringed their copyright as it reproduced a substantial part of their work. ${ }^{34}$ The case revolved around a London red double decker bus against a black and white background of the Houses of Parliament and Big Ben.

Temple Island Collections Ltd maintained that it was

a clear case of infringement. At the crudest level the two images in question simply look strikingly similar. There are a myriad of ways in which a bus could be portrayed in front of the Houses of Parliament that would not have been inappropriately based upon the claimant's work yet the defendants have done so in a way which is very similar indeed to the claimant's work..$^{35}$

The defendants in denying infringement pointed out the widespread and publicly available images of red buses and the Houses of Parliament as well as other common themes present in the defendants' work. The crossexamination focused on how the defendants' work had been produced. ${ }^{36}$

In considering the evidence, the Court summarised it as follows:

The Houses of Parliament, Big Ben and so on are iconic images of London. So too is the Routemaster bus.

The idea of putting such iconic images together is a common one. That includes in particular the idea of an image of Big Ben and the Houses of Parliament with a London bus on Westminster Bridge (or the road nearby).

The technique of highlighting an iconic object like a bus against a black and white image is not unique to the claimant.

Whether anyone had ever produced a black and white image of Big Ben and the Houses of Parliament with a red bus in it before Mr Fiedler [the claimant] is not clear. ${ }^{37}$

On the point of originality, Judge Birss QC focused on the claimant's own intellectual creation in accordance with the Infopaq judgment of the CJEU.$^{38} \mathrm{In}$ this regard, Judge Birss considered the claimant's choices relating to the basic

\footnotetext{
${ }^{33}$ Temple Island Collections Ltd v New English Teas [2012] EWPCC 1.

${ }^{34}$ Ibid., para. 9.

${ }^{35}$ Ibid., para. 11.

${ }^{36}$ Ibid., para. 15.

${ }^{37}$ Ibid., para. 49.

${ }^{38}$ C-5/08 Infopaq [2009] ECR I-6569 = ECLI:EU:C:2009:465, para.51.
} 
photograph itself: the precise motif, angle of shot, light and shade, illumination, and exposure, and also the work that was carried out after the photograph was taken to manipulate the image to satisfy his own visual aesthetic sense. Judge Birss went on to determine that "the fact that it is a picture combining some iconic symbols of London does not mean the work is not an original work in which copyright subsists. The fact that, to some observers, icons such as Big Ben and a London bus are visual clichés also does not mean no copyright subsists. It plainly does. ${ }^{39}$ Judge Birss drew attention to particular elements worthy of attention in the picture, including its composition and artful visual contrasts. ${ }^{40}$

Focusing also on 'substantial taking', ${ }^{41}$ Judge Birss QC finally held that the defendants' work did reproduce a substantial part of the claimant's artistic work:

In the end the issue turns on a qualitative assessment of the reproduced elements. The elements, which have been reproduced, are a substantial part of the claimant's work because, despite the absence of some important compositional elements, they still include the key combination of what I have called the visual contrast features with the basic composition of the scene itself. It is that combination which makes Mr Fielder's [the claimant's] image visually interesting. It is not just another photograph of clichéd London icons. ${ }^{42}$

In concluding the arguments, Judge Birss QC stated that the collection of other similar works relied on by the defendants had worked against them because 'the collection had served to emphasise how different ostensibly independent expressions of the same idea actually look' ${ }^{43}$

Common elements were also the focus of a case concerning magic, wizardry and other elements used in the popular Harry Potter series. In this case,${ }^{44}$ the Amsterdam District Court found in favour of J.K. Rowling, the author of the Harry Potter series, and prohibited the distribution of 7,000 copies of a book by Russian author Dimitri Yemets entitled Tanja Grotter and the Magic Double Bass, derived from the book Harry Potter and the Philosopher's Stone. 'A strong resemblance between the two main characters and the structure

\footnotetext{
${ }^{39}$ Temple Island Collections Ltd v New English Teas [2012] EWPCC 1, para. 51.

${ }^{40}$ Ibid., para. 52.

${ }^{41}$ Designer Guild Ltd v Russell Williams (Textiles) Ltd [2000] 1 WLR 2416.

${ }^{42}$ Temple Island Collections Ltd v New English Teas [2012] EWPCC 1, para. 63.

${ }^{43}$ Ibid., 67.

${ }^{44}$ Joanne Kathleen Rowling, Uitgeverij de Harmonie BV, Time Warner Entertainment Company LP v Uitgeverij Byblos BV [2003] ECDR 23 (Rechtbank Amsterdam).
} 
(prologue, plot, headway, climax, anti-climax and ending) of both stories ${ }^{45}$ were at issue in this case.

The defendant, the Dutch publisher, argued that a plot or a storyline does not in principle fall under the scope of copyright protection. As Rowling uses many elements in her books that are in the public domain (for example, an orphan with mean stepparents, children with magic powers, magic objects, flying on broomsticks), the result is that her copyright protection is diminished. The defendant further argued that similarities with the book Harry Potter and the Philosopher's Stone cannot be considered an imitation as these are also elements that Dmitri Yemets, like Rowling, took from the public domain. ${ }^{46}$

The District Court held, granting the application, that having regard to the high degree of similarity between the two stories, Yemet's book was an adaptation of Rowling's book that cannot be considered to be a new and original work for the purposes of Article 13 of the Dutch Copyright Act 1912 (as amended):

It must be assumed in these proceedings that a storyline (a worked-out plot) can have an adequate character of its own to be considered a work for the purposes of the Copyright Act. This is the case when the plot of the story is original and a place is given in the plot to not necessarily original characters and elements. Byblos' argument that Rowling has used elements from the public domain in her book Harry Potter and the Philosopher's Stone does not in principle affect the possibility that the Rowling's book (in which the storyline is developed) is a work for the purposes of the Copyright Act. ${ }^{47}$

On the point of parody, the Court held that 'by and large, a ridiculous (ironic) imitation of a work can be considered as a parody, where that work becomes the subject of laughter and when the contrast with the original work dominates'. ${ }^{48}$ The aim should be humour and not competition. The Court found that Tanja Grotter and the Magic Double Bass was not recognisable as a parody in terms of the above meaning. ${ }^{49}$

${ }^{45}$ Ibid., para. 3.

${ }^{46}$ Ibid., para. 4.

${ }^{47}$ Ibid., para 5.

${ }^{48}$ Ibid., para. 7. For an in-depth consideration of parody, including a considera- tion of the Dutch parody exception, see D. Mendis and M. Kretschmer, The Treatment of Parody under Copyright Law in Seven Jurisdictions: A Comparative Review of the Underlying Principles (London: Intellectual Property Office, 2013) 1-97.

${ }^{49}$ As confirmed on appeal in Uitgeverij Byblos BV $v$ JK Rowling, Uitgeverij De Harmonie BV and Time Warner Entertainment Co, LP [2004] ECDR 7 (Gerechtshof Amsterdam). 


\subsection{Historical Facts}

Statements of historical fact can have ambiguous status with respect to copyright law. Their incorporation in derivative works has resulted in a number of legal disputes.

In Baigent and Leigh v The Random House Group Ltd ${ }^{50}$ the Court of Appeal dismissed a claim that a work of historical fiction infringed the copyright in a work of history on which it was loosely based. The Court established that the claimants were not entitled to monopolise historical research or knowledge and prevent the 'legitimate use of historical and biographical material, theories propounded, general arguments deployed, or general hypotheses suggested (whether they are sound or not) or general themes written about' ${ }^{51}$

However, the Court recognised the difficulties arising when historical works are drawn upon later by authors, leading to potential copyright infringement based on the taking of a substantial part:

When a book is put forward as being a non-fictional book and contains a large number of facts and ideas it is always going to be a difficult exercise in trying to protect against copying of those facts and ideas because as such they cannot be protected. It is the effort and time that has gone into the way in which those ideas and facts that [sic] are presented that is capable of protection. ${ }^{52}$

Ultimately, it is the manner in which the material is 'assembled' and asserted to constitute the book's design that is important. Historical facts, in isolation, are considered to reside in the public domain; however, the combination and presentation of those facts, when taken together, may create a 'work' and attract copyright protection.

Consideration of these cases highlights the challenges and risks potentially faced by a creator seeking to use ideas in the public domain which on their own would not attract copyright. It appears that UK law is ambivalent on this point, treating facts in some works as copyright material (typically directories and other compilations), but tending to treat them as unprotected when contained in a work which contains substantial amounts of expression..$^{53}$

\footnotetext{
${ }^{50}$ [2006] EWHC 719 (Ch).

${ }^{51}$ Ibid., para. 156. See also H. Laddie, P.S. Prescott and M. Vitoria, The Modern Law of Copyright and Designs (4th edn, London: Butterworths, 2011) Part II, ch. 3.85(5).

${ }^{52}$ Baigent v Random House Group Ltd [2006] EWHC 719 (Ch) Mr Justice Peter Smith para. 260.

${ }^{53}$ M. Sherwood-Edwards, 'The Redundancy of Originality' (1995) 6(3) Ent. L.R. 94
} 


\section{'UNDERLYING IDEAS' NOT APPROPRIATING SUBSTANTIAL EXPRESSIONS}

Creativity is a communicative activity, and artistic creations are in conversation with other works. But how much inspiration can be taken from an existing expression without infringing the copyright of the owner? Can inspiration which is taken, but does not infringe, be thought to exist in the public domain? If so, what is the shape of that public domain, and how can its value to society be enumerated?

Legal and literary scholars Grosheide and Rose have commented on this feature of creativity by surveying the public domain through the lens of copyright's idea-expression dichotomy. F. Willem Grosheide, referring to Erasmus,${ }^{54}$ characterises the historical 'commonplace book' as a 'storehouse of the mind' ${ }^{55}$ Using the metaphor of the beehive, which enables an owner to transform stored honey into any product of its own making, he characterises the public domain as 'a place where readers might store their intellectual honey in order to use it later in their own works' ${ }^{56}$

Mark Rose employs a similar concept of permeation to describe a porous boundary between inspiration drawn from the public domain and new creative endeavour. He states: 'copyright depends on drawing lines between works, on saying where one text ends and another begins. What much current literary thought emphasises, however, is that texts permeate and enable one another, and so the notion of distinct boundaries between texts become difficult to sustain. ${ }^{57}$

The concept of 'permeation' is of particular importance in considering the public domain in the context of the digital landscape and collaborative authorship, where intertextual and collaborative authorship have become more commonplace.$^{58}$ It is therefore imperative to consider the impact of copyright status on digital creativity, particularly if the objective is to stimulate innovation and creation of new works.

However, discerning creative elements which are in the public domain in a concrete sense using this definition is difficult. When considering features

\footnotetext{
${ }^{54}$ Desiderius Erasmus Roterodamus, 1466-1536.

55 F.M Grosheide, 'In Search of the Public Domain during the Prehistory of Copyright Law' in Waelde and MacQueen, n. 8 above, 16.

56 Ibid.

${ }^{57}$ Rose, n. 2 above, 3.

${ }^{58}$ H. Jenkins, Fans, Bloggers, and Gamers: Exploring Participatory Culture (New York: NYU Press, 2006); R Cover, 'Audience Inter/active: Interactive Media, Narrative Control and Reconceiving Audience History' (2006) 8(1) New Media \& Society 13958.
} 
such as genre, plots, characters and events, which lie at the boundary of the idea/expression dichotomy, there are no clear and general rules about what is available for uptake and what is protected.

\subsection{Uses and Challenges}

Creators may consciously choose to take inspiration from another copyright work for a variety of reasons, including aesthetic, political, moral or commercial. This research is focused on commercial exploitation of material in the public domain, and creators were asked about the commercial choices made when selecting and using a particular work or idea.

Some interview respondents reported that they viewed their work in relationship to a constellation of other work in a similar style or genre. For example, one creator interviewed relayed that science fiction authors working in the 'steampunk' genre had appropriated pieces of his own original research, which was itself based on historical events and biographies in the public domain. The historian speculated that such borrowings offered a sense of authenticity, as well as a geographic rootedness to the new fictional work. Other creators reported that identification with a particular style (for example, Victorian London 'gothic noir') helped them connect with audiences that were already knowledgeable about other work in that style.

Genre may also function as a quality signal to potential readers. It is a way of categorising works according to themes and scenarios for a particular group of readers who find them enjoyable. In a publishing market characterised by surplus of choice, genre may help new creators connect with audiences, in a sense making it a tactical commercial consideration for an author to borrow particular genre tropes. ${ }^{59}$

One risk facing creators who take inspiration from other work including plotlines, characters or tropes is that some niche creative communities of producers and audiences are governed by informal social norms that sometimes but not always coincide with the structure offered by copyright law. The result is that a taking which may be permissible to one particular group of creators and fans may not be commercially exploitable in a different market governed by more formal legal rules. This result is frequently seen in efforts to commercialise 'fan' fiction. ${ }^{60}$ Copyright disputes that have arisen have tended

\footnotetext{
${ }^{59}$ M. Wolfe, 'The Apple E-Book Agreement and Ruinous Competition: Are E-Goods Different for Antitrust Purposes?' (2014) 12 Duke L. \& Tech. Rev. 129.

${ }^{60}$ A. Schwabach, Fan Fiction and Copyright (Surrey, UK: Ashgate Publishing, 2011)
} 
to revolve around takings of either structural narrative elements (plots and themes) or characters (in their entirety or as archetypes).

\subsection{Plot, Theme, Genre and Medium}

The rights conferred to authors under sections 16-21 of the Copyright, Designs and Patents Act 1988 extend beyond a simple copyright in the actual language used in an expression. This observation is also expressed by Laddie, Prescott and Vitoria ${ }^{61}$ who provide some guidance in relation to elements such as plot, theme, genre and medium which fall outside a creator's expressivelanguage.

The case of Allen v Bloomsbury Publishing Plc illustrates some of the complexities in this area. ${ }^{62}$ This case concerned an action for infringement of copyright in a book called Willy the Wizard ('WTW') which was written in 1987 by the late Mr Adrian Jacobs ('Mr Jacobs'). ${ }^{63}$ The case brought by Mr Jacobs' estate alleged that Harry Potter and the Goblet of Fire, the fourth book in the well known Harry Potter series of books written by the second defendant, Joanne Murray, popularly known as J.K. Rowling, reproduces a substantial part of WTW and that this constitutes infringement.

The case specifically focused on aspects of the plot, subplots, themes and incidents in WTW as opposed to word for word copying. In considering whether there can be copyright infringement in relation to such elements, the Court took the following view:

Copyright does protect the content of a literary work, including the selection, arrangement and development of ideas, facts, incidents and the like. In assessing the crucial question as to whether a substantial part has been taken, the court must have regard to all the facts of the case including the nature and extent of the copying; the quality and importance of what has been taken; the degree of originality of what has been taken or whether it is commonplace; and whether a substantial part of the skill and labour contributed by the author in creating the original has been appropriated . . Applying these principles in the context of the present case, the similarities upon which Mr Allen relies seem to me to constitute ideas which are relatively simple and abstract and I strongly incline to the view that they are at such a high level of generality that they fall on the ideas rather than the expression side of the line. ${ }^{64}$

\footnotetext{
${ }^{61}$ Laddie, Prescott and Vitoria, n. 51 above, ch. 3, para.3.87.

${ }^{62}$ Allen v Bloomsbury Publishing Plc [2010] EWHC 2560 (Ch); [2010] ECDR 16.

${ }^{63}$ Allen v Bloomsbury Publishing Plc [2010] EWHC 2560 (Ch); [2010] ECDR 16.

${ }^{64}$ Allen v Bloomsbury Publishing Plc [2010] EWHC $2560(\mathrm{Ch})$, paras 85-86.
} 
The issue has also been debated in cases such as Sun Trust Bank v Houghton Mifflin (Gone with the Wind), ${ }^{65}$ in the US, and Cinar Corporation v Robinson, ${ }^{66}$ in Canada. However, similarly to the Willy the Wizard case above, these cases have found in favour of the defendants.

Each of the above cases focused on lesser known works created prior to the popular work. However, what of those works, such as tributes, homages and 'fan' works, which take from existing popular work? In this regard, it is interesting to note the lack of UK cases. As Schwabach states:

The uneasy and unofficial accommodations that exist between many content owners and their fandoms are fragile; eventually a misunderstanding can lead to a lawsuit, and one lawsuit can turn a fandom against the content owner, causing financial damage ${ }^{[67]} \ldots$. As more people ... share their impressions with other readers, a fandom coalesces; this fandom is the most powerful marketing tool a work ... can have. ${ }^{68}$

This may explain why creators of very popular creative works have been slow to take an action of copyright infringement against collaborative creators within specific fandoms. Yet at the same time, fictional characters have proved to be at the forefront of this issue - also in terms of litigation - more so than in the case of plot, theme, genre and so on.

\subsection{Characters}

In considering the protection of characters under copyright law, it can be purported that 'it is not impossible for copyright to be infringed by the parasitic use of another author's character' ${ }^{69}$ This in turn suggests that the individual characteristics of a literary character draw copyright protection, which if copied ('parasitic use') infringe the creator's right. However, as with all copyright protected works, the protection of literary characters also does not rest on 'individual elements' attributed to a character. Instead, it is the collection of attributes, features, well known quotations and so forth which go to make up the imaginary world in which the character moves that amount to a 'substantial part' of the author's original work. However, as UK case law reveals,

${ }^{65}$ Sun Trust Bank v Houghton Mifflin, 60 U.S.P.Q. 2d. 1225 (2001) (11th Cir.).

${ }^{66}$ Cinar Corporation v Robinson 2013 SCC 73, [2013] 3 S.C.R. 1168.

${ }^{67}$ A. Schwabach, Fan Fiction and Copyright (Surrey, UK: Ashgate Publishing, 2011) 92 .

${ }^{68}$ Ibid., 7 .

${ }^{69}$ H. Laddie, P.S. Prescott and M. Vitoria, The Modern Law of Copyright and Designs, Part II: Copyright and Related Rights (4th edn, London: Butterworths, 2011) ch. 40.27 . 
this complex composition of literary characters and their protection under copyright law has met with much uncertainty.

Examination of the UK case law reveals varying approaches to characters and their protection. For example, in Kelly $v$ Cinema Houses $L t{ }^{70}$ it was held that there was no copyright protection in the UK for literary characters. In contrast, in Bolton v British International Pictures Ltd $^{71}$ the Court held that reuse in a later play of two comic telephone repairmen who appeared in eating, drinking and broadcasting scenes of an existing play constituted infringement.

In the same manner, in a case involving the character 'Popeye' in 1941, it was held that 'Popeye' could be protected as an artistic work. The House of Lords was of the opinion that the reproduction, which was based, albeit indirectly, on a number of drawings of the character, was an infringement of the artistic copyright in those drawings and therefore of the character. ${ }^{72}$

Although the UK courts in 1936 and 1941 took a more reserved approach establishing copyright infringement, later cases in 1949, 1991 and 1998 reflect a relaxed approach. In Conan Doyle v London Mystery Magazine ${ }^{73}$ the Court held that Sherlock Holmes' name and address were not protectable, while in Tyburn Productions Ltd $v$ Conan Doyle $e^{74}$ the Court held that Sherlock Holmes and Dr Watson as literary characters are not protected under UK law. In BBC Worldwide Ltd $v$ Pally Screen Printing Ltd ${ }^{75}$ the BBC failed to obtain summary judgment on its claim for copyright infringement of its artwork depicting the 'Teletubbies' against a defendant that printed T-shirts featuring the characters.

Therefore, it is fair to surmise that the copyright status of characters in the UK remains unclear - particularly in comparison to countries such as the US, which has specific tests to determine this concept, resulting in courts upholding protection of a number of fictional characters. In particular, adopting the 'sufficiently delineated' test and the 'story being told' test, the courts in USA

${ }^{70}$ Kelly v Cinema Houses Ltd [1928-35] MacG. C.C. 362, 368 per Maugham J: 'If, for instance, we found a modern playwright creating a character as distinctive and remarkable as Falstaff . . . or as Sherlock Holmes would it be an infringement if another writer, one of the servile flock of imitators, were to borrow the idea and to make use of an obvious copy of the original? I should hesitate a long time before I came to such a conclusion.'

${ }^{71}$ Bolton v British International Pictures Ltd [1936] MacG. C.C. 20. Farwell J held that 'broad comedy characters into a film of this kind, which is based on a tele- phone exchange, I cannot think that there is anything very original about making the comedy characters telephone wire men'.

${ }^{72}$ See also King Features v Kleeman [1941] 2 All ER 403.

${ }^{73}$ Conan Doyle v London Mystery Magazine [1949] 66 RPC312.

${ }^{74}$ Tyburn Productions Ltd v Conan Doyle [1991] Ch. 75CA.

${ }^{75}$ BBC Worldwide Ltd v Pally Screen Printing Ltd [1998] FSR 665. 
have protected characters under 'literary works' ${ }^{76}$ However, a recent ruling relating to Sherlock Holmes demonstrates that the American courts are reluctant to extend the copyright in characters where the copyright term has clearly expired.

In Leslie Klinger $v$ Conan Doyle Estate ${ }^{77}$ Judge Posner established that it is not possible to 'find any basis in statute or case law for extending a copyright beyond its expiration. When a story falls into the public domain, story elements - including characters covered by the expired copyright - become fair game for follow-on authors' ${ }^{78}$ Judge Posner went on to elaborate, stating that 'Holmes and Watson were distinctive characters and therefore copyrightable. They were "incomplete" only in the sense that Doyle might want to (and later did) add additional features to their portrayals. The resulting somewhat altered the characters the alterations do not revive the expired copyrights on the original characters. ${ }^{79}$

\section{WORKS WHERE PERMISSION IS GRANTED}

\section{A PRIORI}

A fourth category of material in the public domain consists of work which has been offered to the public by its creator via unrestricted licence such as the GNU Lesser General Public Licence (LGPL) or Creative Commons (CC) licensing systems. These licensing mechanisms have emerged from within user communities as a response to perceived restrictiveness inherent in copyright: a prospective derivative user of a copyright work must ordinarily request permission from the originator in order to build upon and republish portions of the original work. Seeking permission entails costs, which some communities deem unnecessary and restrictive of creativity in collaborative settings. Free and open public licences allow creators to specify under which conditions a work made available to the public may be further used.

Free and open public licences derive their enforceability from the underlying copyright which the original creator possesses in the work. Consequently, only works which are protectable under copyright, and are the sole creation of the licensor, may be issued under such a licence. Creative Commons licences

\footnotetext{
${ }^{76}$ R. Massey and N. Tian, 'Caught Coming through the Rye - A Purely Literary Character Protected by US Copyright' [2010] Ent. L. Rev. 6-9; A. McGee and G. Scanlan, 'Copyright in Character, Intellectual Property Rights and the Internet: Part 2' (2006) Ent. L. Rev. 15-20.

${ }^{77}$ Leslie Klinger v Conan Doyle Estate, No 14-1128 (7th. Cir., 16 June 2014).

78 Ibid., p.8 of the slip decision, referring to Silverman v CBS, 870 F.2d 40, 4951 (2nd Cir. 1989).

${ }^{79}$ Ibid., 13 .
} 
are nonrevocable, meaning that even if the owner of the work seeks to change the conditions of the licence for new users in the future, anyone who accessed the work under the original terms may continue to use and distribute the work. Under the heading 'Indemnification', the Creative Commons Licencestates:

[Y]ou agree to indemnify and hold harmless the Creative Commons, its employees, officers, directors, affiliates, and agents from and against any and all loss, expenses, damages, and costs, including without limitation reasonable attorneys' fees, resulting, whether directly or indirectly, from or arising out of (a) your violation of the Terms, (b) your use of any of the Services, and/or (c) the content you make available on any of the Services. ${ }^{80}$

Lawrence Lessig, cofounder of Creative Commons, explains the position as follows:

In non-technical terms, the Court has held that free licenses such as the CC [Creative Commons] licenses set conditions (rather than covenants) on the use of copyrighted work ... when you violate the condition, the license disappears, meaning you're simply a copyright infringer. This is the theory of the GPL [another widely used free software licence] and all CC licenses. Put precisely, whether or not they are also contracts, they are copyright licenses, which expire if you fail to abide by the terms of the license. ${ }^{81}$

Put another way, free software licences 'invoke intellectual property rights as the basis for a licensing strategy aimed at preserving the digital commons that the program's developer wished to establish for it' ${ }^{82}$

Because free and open licensing schemes allow creators to specify the types of reuse which are permitted, not all works licensed under such schemes can be thought to exist wholly in the public domain. For example, it could be argued that works licensed expressly for noncommercial purposes are not truly 'public', since many downstream commercial applications of the work would be prohibited. In the context of the free and open source software movement, such noncommercial restrictions reflect the desire to keep software innovation free from enclosure by proprietary users. However, the result is that the size of the 'public' that can make unrestricted use of a work is diminished. ${ }^{83}$

${ }^{80}$ Terms of Use - Creative Commons Master Terms of Use, effective as of 25 May 2018, para. 12, available at http://creativecommons.org/terms (accessed 30 September 2018).

${ }^{81}$ L. Lawrence, 'Huge and Important News: Free Licenses Upheld' (13 August 2008), available at www.lessig.org/2008/08/huge-and-important-news-free-1/ (accessed 31 August 2017).

${ }^{82}$ Samuelson, n. 1 above, 167.

83 Ibid. 
Certain open licences (such as GPL and Creative Commons Sharealike) are viral, meaning that any derivative work created from the original must be issued under the same open licence. This may be beneficial from the point of view of certain users, such as software maintainers wishing to have access to subsequent modifications by third parties which improve and expand the original software code. However, in certain contexts, viral licences may restrict the reuse of the original work. For example, it would be difficult to recombine software code from proprietary sources with other code originating under a GPL licence, since any licence obtained from a third party copyright owner would not likely allow the derivative user to further offer that code to others on an unrestricted, viral basis. ${ }^{84}$ The Free Software Foundation has issued a Lesser General Public Licence (LGPL), which addresses this problem by allowing use of LGPL-licenced code in proprietary software without the requirement of making the entire combined work available, as long as the LGPL-licenced portions remain free and open.

For the purposes of the abovementioned Study, the researchers limited the definition of freely and openly licensed public domain works to those which are licensed on an unrestricted basis allowing both commercial and noncommercial uptake and use. This definition therefore excluded strictly viral licences such as GPL and CC Sharealike, as well as versions of these licences which restrict use to noncommercial purposes. However, the definition included licences where the licensee is still under some obligation (for example to provide attribution for the portions used) but may freely combine it with new work, whether commercial or not.

\subsection{Uses and Challenges}

None of the creators or firms interviewed in the Study reported using work under a free public licence. Similarly, less than 1 per cent of the creative projects analysed on Kickstarter specified that Creative Commons or other freely licensed work formed part of the creative pitch. Several factors might explain the low levels of reported use of freely and openly licensed work in our sample. First, public licensing systems emerged from the Free and Open Source Software movement, where there was a strong initial demand for alternatives to copyright, before later being adapted to other types of creative work. The practice may simply not have had time to propagate to the wider creative community. Since both the creative industries and Kickstarter samples

84 E.S. Samuelsson and M.H. Ulstein, A Brief Comparison of Free and Proprietary Software Licences (2007) Norwegian University of Science and Technology Working Paper. 
included a range of creators working in different mediums (publishing, theatre, illustration, apps and interactive games), the overall proportion of those exposed to open public licensing is likely low. On the other hand, in those domains where free and open licensing is common, such as software, the practice may be so interwoven into the underlying production environment that it goes unnoticed and unreported. There is some evidence for this in our study on Kickstarter. A number of interactive game projects report using the Unity game engine as the basis for their software. The Unity engine is proprietary, but the software includes the open source Mono scripting functionality which is freely and publicly available. Other selected components of the software have been made available by the developers under the unrestricted MIT/ X11 licence. Since our Kickstarter content analysis methodology relied on statements made in the pitch narrative about the intellectual property status of projects, some uses of freely licenced software may have gone unreported by pitch creators, while nevertheless remaining vitally important to the success of the eventual product.

One area identified in the research which made frequent use of freely and openly licensed works was Wikipedia. Some 12 per cent of the images contained in our sample of biographical pages of authors, lyricists and composers were used under unrestrictive open licences such as Creative Commons. The actual rate of use of Creative Commons licensed images on Wikipedia is likely higher, since our sample comprised a large number of subjects whose death occurred more than 70 years ago and where alternative public domain sources were available. The high frequency of freely and openly licensed public domain material on the Wikipedia platform likely reflects the nonprofit status of the collaborative endeavour as well as infrastructure built around related services such as the Wikimedia Commons, which simplifies and channels the contribution of public domain works.

\section{A DEFINITION OF THE PUBLIC DOMAIN FOR EMPIRICAL STUDY}

The traditional legal definition of the public domain takes the copyright term as the starting point, and defines the public domain as 'out of copyright', that is, all uses of a copyright work are possible. A second and third more finegrained definition still relies on the statutory provisions of copyright law, and asks what activities are possible with respect to certain subject matter without asking for permission (for instance, because the subject matter does not qualify for copyright protection, or use relates to 'underlying ideas' not appropriating substantial expressions, or because use is covered by specific copyright exceptions). A fourth definition includes as part of the public domain all uses that are possible under permissive private ordering schemes (such as creative 


\begin{tabular}{|c|c|c|}
\hline Type & Examples (UK) & Included in definition? \\
\hline Works out of copyright & $\begin{array}{l}\text { Term has expired (e.g. literary } \\
\text { and artistic work created by } \\
\text { authors who died prior to } 1944 \text {, } \\
\text { as beyond life of author plus } 70 \\
\text { years term) }\end{array}$ & Yes \\
\hline $\begin{array}{l}\text { Subject matter that does not } \\
\text { qualify for protection }\end{array}$ & $\begin{array}{l}\text { Works never protected (myths, } \\
\text { folklore) } \\
\text { Ideas, not expression (e.g. facts, } \\
\text { inspiration for genre, plots and } \\
\text { characters) }\end{array}$ & $\begin{array}{l}\text { Yes, needs specific assessment } \\
\text { for individual derivations, but } \\
\text { then commercial exploitation is } \\
\text { unrestricted }\end{array}$ \\
\hline $\begin{array}{l}\text { Privileged uses of works (by } \\
\text { statute) }\end{array}$ & $\begin{array}{l}\text { Exceptions (e.g. fair dealing } \\
\text { for news reporting, review and } \\
\text { criticism) }\end{array}$ & $\begin{array}{l}\text { No, since only specific uses are } \\
\text { covered (making exploitation of } \\
\text { derivative artefacts commercially } \\
\text { problematic) } \\
\text { Orphan works could be included } \\
\text { in future study }\end{array}$ \\
\hline $\begin{array}{l}\text { Permitted uses of works (by } \\
\text { licence) }\end{array}$ & $\begin{array}{l}\text { Creative Commons and Open } \\
\text { Source (e.g. GPL) licences }\end{array}$ & $\begin{array}{l}\text { Yes, if permitting commercial } \\
\text { and noncommercial uses, without } \\
\text { downstream restrictions }\end{array}$ \\
\hline Tolerated uses of works & $\begin{array}{l}\text { Some machinima and fan projects } \\
\text { (e.g. comics, books, translations, } \\
\text { games) }\end{array}$ & $\begin{array}{l}\text { No, since toleration is uncertain, } \\
\text { and may be revoked }\end{array}$ \\
\hline
\end{tabular}

commons licences). A fifth definition moves into a space that includes use that would formally be copyright infringement but which is endorsed, or at least tolerated, by certain communities of practice (such as 'machinima' cinematic production of computer games or fan fiction).

Such an expanded view of the public domain would include many more potential uses, such as those enabled via complex boundaries to copyright law, or even uses which are invisible to rightholders. The wider the definition, and the more it focuses on specific legally privileged or tolerated acts, the more difficult it becomes to determine whether a given usage is permitted in every case, producing a lack of clarity for downstream users. One conceptual innovation of this research is that we intend to capture an understanding of the public domain that focuses on the commercial potential for derivative products. In order to assess value, the definition needs to (i) be understandable for participants in the media and entertainment markets, and (ii) cover commercial as well as noncommercial downstream uses. In summary, this study relies on the definition of the public domain set out in Table 4.1. 
The preceding discussion has outlined the rationale for selecting a definition of the public domain which enables empirical capture of works and ideas which are available for uptake by all (commercial and noncommercial) users, and impose no restrictions on downstream exploitation.

\section{SUMMARY OF EMPIRICAL PROJECTS}

The final section of this chapter presents the results of three interrelated research projects drawn from the UKIPO-ESRC Study which examined different aspects of uptake and reuse of works from the public domain. The first project is focused on small and medium sized creative firms in the UK that have used public domain materials as part of their commercial activities. This project uses a qualitative interview method and seeks to develop an understanding about the decisionmaking process within the small firm when it comes to the choice of using material in the public domain, developing original content or licensing work from elsewhere. The second project focuses on a different group of users - small independent producers on the Kickstarter crowdfunding platform. This is a largescale, quantitative study on a selection of 1,993 projects pitched in the first quarter of 2014. This project explores the rate of uptake and performance of public domain materials when they are incorporated in new Kickstarter projects, compared with original and third party copyrighted works. Finally, the third project considers the role played by the public domain status of images in the rate of their usage on Wikipedia and attempts to assign a value to that availability based on measurements of the improvement of page visitorship after the addition of an image is detected. Observations from the three research activities are then discussed, and implications for policy are used to generate recommendations for future action.

\subsection{Project 1: Commercial Uptake by Creative Businesses}

This study consisted of interviews with 22 creative businesses that used public domain materials to create commercial products. Research explored why firms made decisions to invest in development of public domain projects, finding four main types of use: (i) engagement with fan community of existing literary work; (ii) inclusion of public domain material to complement a technological platform or subscription service; (iii) conscious entrepreneurial strategy based on identification of existing demand; and (iv) partnership with a public institution to celebrate and engage the public with regard to an event or anniversary 
of significance. Researchers identified the following issues relating to public domain uptake:

- Creators working with visual or multimedia content reported difficulties in locating and securing high-quality sources of public domain works (image resolution, digital formats). This was a significant challenge to commercialisation.

- Archives, museums and libraries were frequently cited as useful partners when seeking access to public domain works, able to provide access to source material and data needed to ascertain the copyright status of a work.

- There was little concern about competition due to nonexcludability of source material, but firms worried about costs of marketing and sustaining public domain projects when initial development cost and investment was also low.

- The public domain status of inputs to the creative process permitted certain business models to flourish, particularly those where fan creativity was integral to the value generation process.

- Clarity on legal use (e.g. requirements for 'diligent search' when using orphan works) would improve commercialisation potential.

\subsection{Project 2: Public Domain Projects on Kickstarter}

Crowdfunding platforms such as Kickstarter appear to be governed by an ethos which rewards originality and niche production. However, not all intellectual property (IP) on the platform is new and original. Often, pitch creators incorporate IP from a third party rightholder, as well as material from the public domain. In order to assess the role of public domain material in a crowdfunded creative marketplace, we performed quantitative analysis on 1,933 Kickstarter projects from January to April (Q1) 2014. We used binary logistic regression analysis to model likelihood of success of projects when different underlying copyright or public domain material was present. The main findings were as follows:

- Use of both public domain and third party licensed material was significantly associated with higher likelihood of project success, compared to 'original' projects that did not incorporate such material.

- The influence of the public domain status on the success rate was most pronounced in the mediums of comics and theatre, compared with publishing and video games. This suggests that the role of public domain materials differs across mediums. Direct republication of public domain literature does not seem to be rewarded - adaptation to another medium may be more attractive to consumers. 
- Explicitly obtaining copyright permission to use a third party work in a Kickstarter pitch was significantly associated with higher funding levels achieved.

- Previous experience and status of the pitch creator was also significant to the project success, suggesting that familiarity with both the underlying work and its creator is important to Kickstarter funders.

\subsection{Project 3: Impact of Availability of Public Domain Images on Wikipedia $^{85}$}

Wikipedia is an important global resource and is itself emblematic of the digital public domain, being free for uptake by commercial and noncommercial users alike. Much of the written content on Wikipedia is supplied by volunteer contributors. However, supplemental material such as photographs and illustrations must be used in such a way to ensure the openness and availability of articles to downstream users. Consequently, the Wikipedia platform potentially benefits from availability of photographs and illustrated material in the public domain (either due to copyright term expiration or open and unrestricted licensing). To assess the value of public domain images in the context of this resource, researchers studied the presence and impact of public domain images on biographical Wikipedia pages of 1,700 literary authors, lyricists and composers. Broadly, the study finds that the 'background' availability of public domain material has an effect on the rate of inclusion of images, as well as a measurable impact on the performance of those article subpages benefiting from visual enhancement offered by public domain images.

Public domain availability makes a significant difference to inclusion of images on Wikipedia. Biographies for notable authors born prior to 1880 have a greater likelihood of containing an image than those born more recently, even though camera technology became widespread in the twentieth century. Less than 58 per cent of authors in the sample born after 1880 have images associated with their Wikipedia pages.

Controlling for notoriety of authors, composers and lyricists using a matched pairs technique, we found that pages with public domain images attracted between 17 and 19 per cent more visitors than pages where no image was available, reflecting the value those images contribute to the Wikipedia resource.

85 This project has been fully written up in P. Heald, K. Erickson and M Kretschmer, 'The Valuation of Unprotected Works: A Case Study of Public Domain Photographs on Wikipedia' (2015) 28 Harvard J. L. \& Tech. 1. 
Using commercially equivalent licence fees obtained from Corbis and Getty for images relating to the biographical sample, we estimate a total value of US\$208 million (GB£138 million $^{86}$ ) per year for the 1,983,609 English language Wikipedia pages in appropriate categories which contain public domain images.

\section{CONCLUSION}

The public domain is vast and - depending on one's definition criteria dependent on the context and type of use envisaged. However, the public domain matters to society and the economy only when it is used. It is not only the legal status of a work itself that matters but also the transformative potential (which requires awareness among the relevant communities of practice). Based on the UKIPO-ESRC Study, this chapter attempted to define the public domain according to a set of criteria which conceptually limit the scope of the study to include only materials and works that are available for uptake by all potential users within the UK. Even using this definition, the boundaries of the public domain are not always clear. For example, court rulings leave ambiguity about which creative aspects of an expression might constitute 'common elements' and which takings might infringe. The inability of potential creators and entrepreneurs to rely on criteria to ascertain, predictably, the status of materials as in the public domain is a theme which emerges strongly from the preceding analysis.

The empirical projects reported here represent choices about the most appropriate field sites for gathering data in support of a larger assessment of the 'value' of the public domain. The researchers sought to supply robust empirical evidence on the performance of public domain materials in a limited number of specific markets.

Prior to this Study, there have been a number of attempts of varying methodological sophistication to calculate the total contribution of categories of economic activity to national accounts as 'copyright industries' ${ }^{87}$ The present

\footnotetext{
${ }^{86}$ Based on the exchange rate calculated on 25 January 2015, at the time the UKIPO-ESRC Project was carried out.

87 World Intellectual Property Organization (WIPO), Guide on Surveying the Economic Contribution of the Copyright-Based Industries (Geneva: WIPO Publication No 893 (E), 2003); World Intellectual Property Organization (WIPO), The Economic Contribution of Copyright-Based Industries in Canada, Creative Industries Series No 1 (Ottawa: Wall Communications, 2004); World Intellectual Property Organization (WIPO), WIPO Studies on the Economic Contribution of the Copyright Industries (Geneva: WIPO, 2014), available at: www.wipo.int/export/sites/www/copyright/en/ performance/pdf/economic_contribution_analysis_2014.pdf (accessed 30 September
} 
research makes no such claims to offer a total 'value' of the public domain in terms of UK GDP. However, the results of both the qualitative and quantitative studies undertaken point to a major flaw in previous attempts to enumerate the total value represented by copyrights to the overall economy: generation and exploitation of products which attract copyright cannot easily be disentangled from other public domain 'inputs' to that same creative production; nor can the increasing number of creative outputs, such as those offered under free and unrestricted open licences, be easily counted as part of a tabulation of the contribution by 'copyright industries' .

Indeed, a key finding of the research is that creative managers who report success with exploitation of public domain materials also report experience with licensing and exploitation of copyrighted works. The knowledge required for assessing the copyright status and availability of a work in the public domain in many cases complements a business strategy of pursuing hybrid IP portfolios that incorporate a suite of products with different IP arrangements. In the Kickstarter project, some 33 per cent of projects sampled incorporated a combination of both copyrighted and public domain material in the final product, suggesting that recombination of different sources of IP - some licensed and some freely available - may be emerging as a common practice.

When it comes to assessing the performance and value of public domain inputs to the production practices that we observed, overall findings suggest that products inspired by the public domain do perform well. Public domain materials appear to attract a higher rate of funding and success on the Kickstarter platform, likely because public domain materials are familiar to potential backers and operate as a signal of quality in a market characterised by information asymmetry and high risk. UK firms that have used public domain materials successfully report benefits at different stages in the value chain. Some firms have built proprietary technologies as wrappers around public domain material, which is later commercialised at little additional marginal cost alongside other licensed copyrighted works; some firms develop original content within a user community of fans and consumers of a public domain work, producing creative products which connect intertextually with other media offerings; finally, some creative firms working on public domain materials find ways of connecting with public stakeholders around issues of local and national significance, essentially enrolling citizens into the value chain as coproducers. Some firms use a combination of approaches and it is likely that new approaches will be developed. The theoretical proposition that overgrazing will diminish the value of public domain materials does not appear

2018); United States Patent and Trademark Office, Intellectual Property and the U.S. Economy: Industries in Focus (U.S. Department of Commerce, 2012). 
to be a significant concern - firms are innovating with public domain material despite the absence of an exclusive right in the source material. They are doing so because there are attractive aspects to working with public domain inputs that do not depend on excludability.

In summary, the main empirical findings from the Study are:

- The public domain is important; there is demand and innovative potential for public domain derived materials.

- There is a lack of knowledge among practitioners as well as a gap in terms of information services (archives, searchability, metadata).

- Similar skills appear to be required for commercially sourcing copyright materials as for identifying and exploiting the public domain.

- Overexploitation (sometimes called 'overgrazing') does not appear to be a concern for creative managers, who tailor their business strategy.

- GDP accounting for the size of the 'copyright industries' needs to be supplemented by quantification of alternative inputs (such as economic activities relying on the use of public domain materials). 